\title{
Economic Empowerment Policies and Economic Growth in the Post-Apartheid South Africa - A Cointegration and Granger Causality
}

\author{
Dr R Ncwadi \\ Department of Economics \& Economic History, P O Box 77000 \\ Nelson Mandela Metropolitan University, Port Elizabeth 6031, South Africa \\ Email: ronney.ncwadi@nmmu.ac.za \\ Ms S Onceya \\ Department of Economics at Fort Hare University, Alice, South Africa. \\ Ms B Siswana \\ Department of Economics at Fort Hare University, Alice, South Africa
}

\section{Doi:10.5901/mjss.2014.v5n10p268}

\begin{abstract}
After the first democratic elections in 1994 there was a need to develop policies, strategies, laws and other means to address huge inequalities of wealth and economic options that the long-term apartheid policies had created. An economic transformation strategy formed part of government's strategic approach to ensure accelerated and shared growth in South Africa. Empowerment was characterized by giving access to economic resources through entrepreneurship as well as affirmative action policies. A cointegration approach on a time series during the period 1995 to 2009 is employed in this study. The results of our analysis prove that racially biased policies have a negative impact on the economy of South Africa in the long run.
\end{abstract}

Keywords: Black Economic Empowerment, Affirmative Action, Economic growth, Vector Error Correction Model

\section{Introduction and Background}

Black Economic Empowerment is a widely debated topic in South Africa, with a number of people believing that BEE aggravates a racial divide in terms of resource ownership whilst others believe that the benefits of BEE are narrowly distributed with little or no impact on economic growth in South Africa. A large number of whites believe that racial preferred policies which are being implemented in South Africa are nothing but a reversed apartheid system. During the apartheid era, the economy of South Africa was struggling to grow, due to disinvestments and global isolation. The economy was characterised by high unemployment rates, poverty and low productivity levels. The distribution of resources was skewed along racial lines. In this respect, the qualities and capabilities of the individuals were ignored in favour of race. Jobs were reserved for whites whilst a number of blacks who were competent enough were displaced. This led to misallocation of resources during apartheid.

After the first South African democratic elections in 1994, policies seeking to redress the imbalances of the past were enacted. Amongst others, Black Economic Empowerment (BEE) was a policy established to redress the socioeconomic inequalities caused by the apartheid regime. Despite many economic gains made in South Africa since 1994, the economic racial segmentation between the rich and the poor intensified and these inequalities were leading to a political instability, hence the formation of BEE. BEE is about economic empowerment of all black people including women, workers, youth, people with disabilities and people living in rural areas through diverse but integrated socioeconomic strategies that include, but are not limited to increasing the number of black people that manage, own and control enterprises and productive assets; facilitating ownership, management of enterprises and productive assets by communities, workers, cooperatives and other collective enterprises; human resource and skills development; achieving equitable representation in all occupational categories and levels in the workplace preferential procurement and investment in enterprises that are owned or managed by black people (Government Gazette, 2004). 
In an attempt to achieve a BEE compliant culture, already existing big enterprises and qualifying medium enterprises had to be BEE compliant after 2004. This had to be measured with a yardstick that is called the code of good practice. Relevant issues surrounding the measurement of BEE needed to be addressed to further accelerate transformation process and growth. The codes of good practice address the obstacles and challenges that resulted in the apartheid legacy. Each challenge in BEE is set to have a solution through these codes. BEE led to the formation of a broad-based approach rather than the narrow-based black economic empowerment and a strategy for Broad-based Black Economic Empowerment was released in 2003 (DTI, 2007).

This strategy was followed by Broad-Based BEE Act No 53 of 2003 which was publicised in 2004. The Act entails elements such as licensing and concessions criteria, development and implementation of a preferential procurement policy. This policy was based on the idea that black owned businesses must be prioritised whenever a service is needed by private and public entities. Secondly it led to the determination of qualification criteria for a state-owned enterprise. Public-private partnerships are encouraged to allow black small businesses to have a stake in private profits in order to achieve growth and to diminish a single beneficiation method encouraged by companies. But before we can debate on the impact of BEE on economic growth it is important that we explore the rationale for black economic empowerment.

\section{A Rationale for Growth through Black Economic Empowerment}

Black Economic Empowerment policy came into view as a potential mechanism for dealing jointly with structural issues affecting economic growth and racial access. This policy is fundamentally meant to empower black people in entrepreneurship and ownership of resources. The policy requires firms to change capital and control structures, management structures, and procurement relationships, activities involving enterprise development and the way they engage with society more broadly. These requirements are reflected in Codes of Good Conduct and a scorecard for assessing BEE status of the various firms in South Africa. According to Sanchez (2011) the scorecard approach has encouraged the voluntary development of industry transformation charters across a wide range of sectors. The charters establish clear indicators for companies and serve as guidelines for empowerment requirements across the different industries. Even though they established their own guidelines they are aligned with the codes provided by government. Whereas the framework has been constantly adapted to facilitate compliance, the pressure for big companies to transform is intensifying. For case in point, 2012 is one of the milestones for achieving transformation targets and move on to even more rigorous transformation targets. After this recent amended Broad Based Black Economic Empowerment codes of good practice (2012) companies will be expected to have more ownership in black hands (increased from 20 to 25), more black employees and managers and to procure even more from black businesses.

The kind of structural change is apparent even in narrow versions of BEE. The emphasis on transferring ownership and management of some large firms to new black entrants implies opening up capital and control structures. Even a few new entrants suggest some capital de-concentration and more black and female faces in board rooms bring possibilities for new ideas, new ways of thinking and new connections to networks. Shubane (2007) states that de-radicalising economic activities in South Africa is a necessary condition for growing the economy. According to Macozoma (2007) "in order to succeed economically and grow the economy further, the country must clearly harness the energies of as many people as possible from across the racial divide". The then deputy state president President Ms Mlambo Ngcuka stated that, 'The elite benefiting from the first economy must intervene and help people in the second economy' and that new BEE partners' must see their deals and activities as a mechanism to create more jobs for those who are outside the mainstream' (Daily Tenders 2005). A successful inclusion of the previously disadvantaged individuals (PDIs) to the mainstream economy helps to open the economy to new ideas, entrepreneurs, and labour-absorbing, export-enhancing activities. The consequence of this process should provide a catalyst for economic growth in South Africa. It therefore follows that a key issue in the South African economy is a link between economic growth and BEE. The growth performance of the economy determines the resources available for redistribution and transformation and arguably the best contribution that BEE can make is to contribute towards the new growth. In this regard BEE is considered a catalyst for economic growth in South Africa through fostering entrepreneurship.

\section{Overview of BEE Implementation in South Africa}

Despite the fact that the impact of BEE is a contested issue and many challenges remain, the BEE strategy has according to Sanchez (2011) on the whole created a roadmap for empowering underprivileged individuals and facilitated access to opportunities and financial resources for many black South Africans. The most visible outcome perhaps is that today South Africa has a growing middle class which did not existed before 1994. 
Socio-economic transformation, particularly along racial lines is a long and complex process. But regardless of the setbacks, BEE is a clear attempt to address the injustices of the past and has put the issue of economic and social transformation clearly as a priority in the country's development agenda (Sanchez, 2011). Through an assertive public discourse on the need to empower the disenfranchised black majority as a moral obligation, the private sector has been encouraged to participate in the country's transformation.

.Moreover, Van der Berg and Louw (2004) cites that as companies have gained some degree of social consciousness and most importantly the need to do business with black Small, Micro and Medium Enterprises (SMMEs) in order to do business with government, BEE seems to be encouraging a stronger corporate social responsibility (CSR) and notably economic agenda. This is for instance reflected on the increasing corporate social investment (CSI) spending since the country's democratization. Furthermore, the consultative approach of the BEE strategy has opened spaces to strengthen the dialogue between government and the private sector and fast-tracked the recognition of gender inequalities, offering specific initiatives and incentives to close the gender gap.

The birth of Broad Based Economic Empowerment (BBB-EE) black players in the post apartheid area looks back to the emergence of influential and powerful Afrikaner players after 1948. The BBB-EE players are a much focused elite group emerged since 1994. In figures below, the before BBB-EE compliance companies' situation is indicated and compared with the scenario after BBBEE (van Scheers, 2010).

Figure 1: South African economic ownership before and after BEE policies

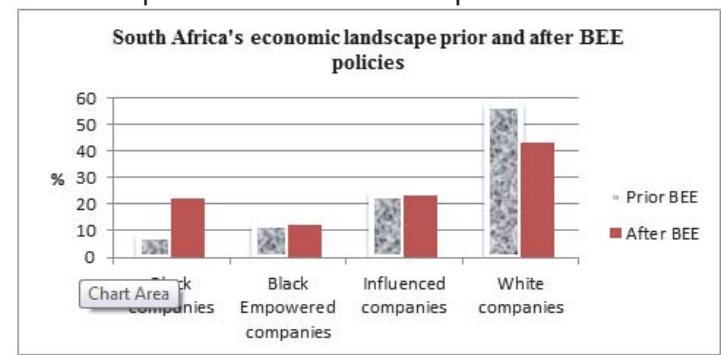

Source: Problems and Perspectives in Management (2010)

Figures above indicates concerto of companies before and after the government's BBBEE policy application in the South African Economically active sectors. Comparison study (figure 1 above) shows that before the BBB-EE compliance policy, approximately eight percent of the South African companies were black companies, compared to 22 percent after the government applied their determined BBB-EE policies.

\subsection{Management control process}

Figure 2 below shows the progress made against the set code targets in terms of management control within companies.

Figure 2: Management control process: 2012

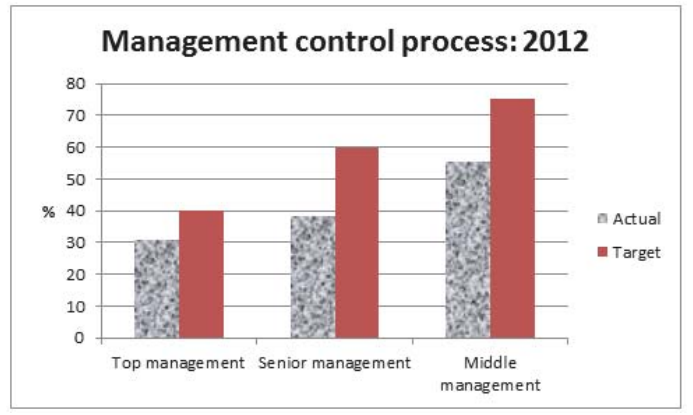

Source: DTI (2012)

DTI (2012) indicates that in terms of the targeted $40 \%$ of blacks occupying top management position so far the progress is at $30.80 \%$, those in senior management positions are at $38 \%$ against the target of $60 \%$ whereas middle management actual is at $56 \%$ against the targeted $75 \%$. 


\subsection{Generic Scorecard Broad Based Black Economic Empowerment Trend Analysis}

The Codes of Good Conduct and a scorecard are used to assess BEE status of the various firms in South Africa. The scorecard approach has encourages the voluntary development of industry transformation charters across a wide range of sectors. Table 1 below shows an upward trajectory in the BBB-EE scorecards.

Table 1: Generic scorecard BBB-EE trend analysis

\begin{tabular}{|c|c|c|c|c|c|c|c|}
\hline Element & Target & 2006 & 2007 & 2008 & 2009 & 2010 & 2011 \\
\hline Ownership & 20 & 8.00 & 10.82 & 8.46 & 13.86 & 11.29 & 13.43 \\
\hline Preferential Procurement & 20 & 6.00 & 10.80 & 8.69 & 10.24 & 12.36 & 15.99 \\
\hline Employment Equity & 15 & 5.00 & 5.42 & 5.11 & 7.41 & 7.02 & 7.09 \\
\hline Skills Development & 15 & 7.00 & 6.06 & 5.72 & 10.00 & 6.00 & 7.92 \\
\hline Enterprise Development & 15 & 3.00 & 7.82 & 7.94 & 7.24 & 10.46 & 12.41 \\
\hline Management Control & 10 & 4.00 & 7.71 & 6.15 & 5.51 & 4.16 & 5.57 \\
\hline Socio-Economic Development & 5 & 4.003 & 3.20 & 4.04 & 5.00 & 3.74 & 4.51 \\
\hline Total & 100 & 37.00 & 51.83 & 46.11 & 59.26 & 55.03 & 66.92 \\
\hline
\end{tabular}

Source: KPMG BEE Survey, 2011

As per the KPMG survey (2011) scores show evidence of an upward trend between 2006 and 2011, on average moving from level eight contributor to level four. A further significant improvement is the respondents increased efforts towards supporting small black-owned business entities as it can be noted in the increase in enterprise development from 2006 to 2011.

\subsection{BEE Transactions}

Figure 3 below shows the amount of BEE transactions in billions of Rands from 1995 to 2009.

Figure 3: BEE Transactions: 1995-2009

\section{BEE TRANSACTIONS : 1995-2009}

(in R'bil)

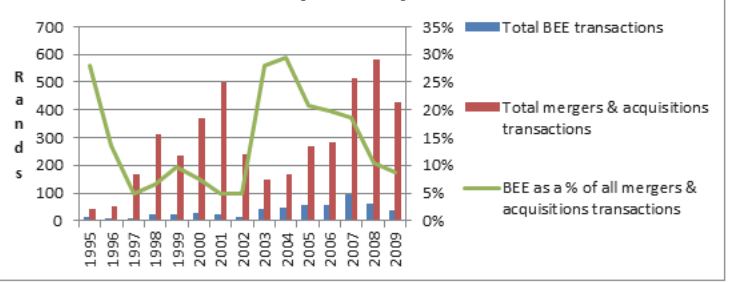

Source: Economic indicators (2010)

Total BEE transactions have been on the increase from 1995 to 2007 but began to spiral downwards from 2008 to 2009. This downward trend from 2008 to 2009 can be attributed to the effects of the global economic meltdown. The total mergers and acquisitions transactions were in an upward trajectory since 1995 but began tapering down as early as 2002 and took a further downward knock in 2003/2004. However, from 2005 through to 2008 total mergers and acquisitions began to climb upwards. This upward trajectory was also slowed down by a global economic downturn and began to spiral downwards. When looking at BEE transactions as a percentage of total mergers and acquisitions, one would note that BEE transactions as a percentage of total mergers and acquisitions took a nose dive between 1995 to 1997 from $28 \%$ to almost half (14\%) in 1996/1997 but began to climb upwards from 1998 to 1999 . This upward trend began to tapper down from 2000 through to 2002 but then climbed upwards to almost similar level as that of 1995 in 2003 and 2004 reaching $28 \%$ and $30 \%$ respectively. However from 2004 to 2009 BEE transactions as a percentage of total mergers and acquisitions transactions spiralled downwards to a low level of $9 \%$ by 2009 without any signs of upward trend.

Given the above scenario regarding an overview of BEE performance in South Africa, a question that remains is whether or not BEE leads to economic growth in South Africa. 


\section{Problem Setting}

Some observers point out that white firms engage in charter development to minimise the impact of BEE. In line with this thinking some observers suggest that BEE is not a catalyst for transformation and economic growth in South Africa. Meintjies (2004) states that black economic empowerment has mixed results with very little being achieved in terms of changing structures of ownership, control over the economy and economic growth. Jack (2007) also expresses reservations about the impact of black economic empowerment policies on the economy of South Africa pointing out that most companies only want to do the least in complying with BEE policies irrespective of the ultimate effect and quality of the outcome. This attitude is reflected in the level of fronting that takes place and the unsustainability of BEE deals and initiatives that are being implemented. In a study by Sadler (2001) black Chartered Accountants in some of the South African large firms were surveyed about their feelings concerning their involvement and control in the companies for which they worked. A large number of them expressed opinion that limited assignments were given to them, supervisors were racially biased and there was a huge lack of black mentors. This was coupled with a lot of resistance from other large white owned firms to use services of black auditors. Accordingly, Pressly (2007) expresses a view that the private sector is its own worst enemy as it shows a complete disregard of transformation agenda in South Africa.

A further concern about the implementation of BEE in South Africa is the fact that very few companies on the Johannesburg Stock Exchange are black and very little of the company value added ends up in black hands (Gqubule, 2006). The problem is further aggravated by the so-called cronyism whereby only those who are politically connected benefit from empowerment transactions.

Concerns over the narrow gains from BEE implementation in South Africa is informed by data showing an expanding inequality gap amongst the rich and the poor in South Africa. Between 1995 and 2005 the gini coefficient increased from 0.50 to 0.62 (Deutsche Bank, 2006). The rise in inequality gap figures is driven by a widening income gap within black population which rose from 0.50 to 0.62 during the same period ((Deutsche Bank, 2006). In relation to this, authors like Blade Nzimande (2007) and Moeletsi Mbeki (2007) decry the narrow ownership transactions of the early BEE period and warned about an elitist approach to change that minimises change itself. Meintjies (2004) points out that BEE is created and driven by the elite in government and elite and white businesses. If gini coefficient can be anything to go by, one can argue that the structural gap between the insiders and elites and the outsiders has grown since BEE was introduced. This could be the result of increased empowerment at the top of the economy increased disempowerment at the bottom of the economy or a mixture of the two. Southall (2005) express an opinion that the entrenched structural impediments in the economy are the main reasons for BEE not impacting positively in the economy of South Africa.

\section{Rationale for the Study}

Black economic empowerment policies are geared to transform the economy of South Africa through fostering entrepreneurship. Economic transformation can only be effective in a growing economy. Resources are scarce whilst the population is growing. It therefore makes sense that economic transformation should be driven in a growing economy. Sharing a cake of a fixed size will eventually leave nothing to be shared unless we grow the size of a cake. The significance of this study is based on the fact that there is no record on the impact of BEE on the economy of South Africa. Studies that have been done in the past present a descriptive view of the impact of BEE on the economy by showcasing a number of BEE deals concluded, a sectoral anaylsis of firms with BEE deals as well as the magnitude of transformation within management processes in various firms but no econometric modelling has been done in order to ascertain and forecast the impact of BEE on the economy of South Africa. This study aims to fill this gap.

\section{Objectives of the Study}

- To examine the impact of BEE transactions on the economy of South Africa

- To provide policy recommendations on how to transform BEE into an effective tool for growth in South Africa

\section{Hypothesis}

$\mathrm{H}_{0}$ : Black economic empowerment is not a catalyst to economic growth in South Africa

$\mathrm{H}_{\mathrm{a}}$ : Black economic empowerment is a catalyst to economic growth in South Africa. 


\section{Research Methodology}

The study makes use of a restricted vector auto regression technique using a time series analysis on a quarterly data from 1995 to 2009.

\subsection{Model Specification}

The empirical model is expressed in the following functional form:

$\mathrm{GDP}_{\mathrm{t}}=\beta 0+\beta_{1} \mathrm{BEE}_{\mathrm{t}}+\beta_{2} \mathrm{Xt}+\beta_{3} \mathrm{GFCl}_{\mathrm{t}}+\beta_{4} F D \mathrm{I}_{\mathrm{t}}+\mu_{\mathrm{t}}$

Where:

$\beta 0, \beta_{1}, \beta_{2}, \beta_{3}$, and $\beta_{4}$ are the coefficients of the variables to be estimated. The above variables were logged so that we obtain the following regression formula:

$\operatorname{InGDP}_{\mathrm{t}}=\beta 0+\beta_{1} \ln \mathrm{BEE}_{\mathrm{t}}+\beta_{2} \ln X \mathrm{t}+\beta_{3} \ln \mathrm{GFCl}_{\mathrm{t}}+\beta_{4} \operatorname{lnFDI}_{\mathrm{t}}+\mu_{t}$

where $\mathrm{ln}=$ natural logarithms.

\subsection{Definition of Variables and Data Sources}

A number of variables are included in the regression equation are as follows:

- Gross Domestic Product (GDP) is the market value of all final goods and services produced within the country in a given period of time. Quarterly time series data for GDP (current market prices) from the first quarter of 1995 to the fourth quarter of 2009 are used in our estimation and have been sourced from Statistics South Africa.

- BEE refers to Black Economic Empowerment transactions in billions of Rands from 1995 to 2009. Quarterly time series data from the first quarter of 1995 to the fourth quarter of 2009 was sourced from Development Indicators (2010).

- X refers to quarterly data on exports in billions of Rands from $1^{\text {st }}$ quarter 1995 to $4^{\text {th }}$ quarter 2009. Data was sourced from Quantec, South Africa.

- $\mathrm{GFCl}$ refers to gross fixed capital formation in billions of Rands from $1^{\text {st }}$ quarter 1995 to $4^{\text {th }}$ quarter 2009.

- FDI refers to foreign direct investment in billions of Rands from $1^{\text {st }}$ quarter 1995 to $4^{\text {th }}$ quarter 2009

- $\mu=$ stochastic disturbance

- $t=$ time period

\subsection{A Priori Expectations}

Table 2: Expected relationships with a dependant variable (GDP)

\begin{tabular}{|l|c|l|}
\hline Variable & Expected sign & \multicolumn{1}{c|}{ Rationale } \\
\hline BEE & + & $\begin{array}{l}\text { BEE policies enhance economic activity through entrepreneurship. Such } \\
\text { stimulus should contribute positively GDP (Mohr \& Fourie, 2008) }\end{array}$ \\
\hline X(Exports) & + & $\begin{array}{l}\text { Exports attract foreign currency and this should contribute positively to } \\
\text { economic growth (Appleyard \& Field, 2005) }\end{array}$ \\
\hline GFCl (Gross fixed capital formation) & + & $\begin{array}{l}\text { Gross Fixed Capital Formation is an investment and therefore an injection to the } \\
\text { economy. It is expected to contribute positively to GDP (Mohr \& Fourie, 2008). }\end{array}$ \\
\hline FDI (Foreign Direct Investments) & + & $\begin{array}{l}\text { Foreign Direct Investments constitute an injection to the economy and should } \\
\text { therefore contribute positively to GDP (Appleyard \& Field, 2005) }\end{array}$ \\
\hline
\end{tabular}

\subsection{Estimation Techniques}

The estimation technique used in this study is vector autoregression method. Vector autoregressive models (VARs) were popularised in econometrics by Sims (1980) as a natural generalisation of univariate autoregressive models. A VAR is a systems regression model (i.e. there is more than one dependent variable) that can be considered a kind of hybrid between the univariate time series models and the simultaneous equations models. VARs have often been advocated as 
an alternative to large-scale simultaneous equations structural models. An important feature of the VAR model is its flexibility and the ease of generalisation. A useful facet of VAR models is the compactness with which the notation can be expressed. For example, where $k=1$, so that each variable depends only upon the immediately previous values of y1tand $y_{2 t}$, plus an error term.

VAR models have several advantages compared with univariate time series models or simultaneous equations structural models, for example a researcher does not need to specify which variables are endogenous or exogenous. All variables are endogenous. This is an important point, since a requirement for simultaneous equations structural models to be estimable is that all equations in the system are identified. Essentially, this requirement boils down to a condition that some variables are treated as exogenous and that the equations contain different RHS variables.

It is essential that all of the components in the VAR are stationary. However, most time series data are not stationary in their levels such that estimations based on this technique will be meaningless (spurious). Differencing the variables to mechanically turn them stationary has been a preferred approach to deal with this problem, but it throws away useful long run information that may be in the data. These problems led to the emergence of new generation models based on cointegration and error correction modelling (Brooks, 2002: 400). There are also several cointegration based methods but the majority of them suffer from numerous problems when applied to multivariate models. These include not being able to test for cointegration when there are multiple cointegrating relationships and sample problems amongst others. The technique in this category that has emerged as the most powerful and popular is the Johansen technique, which is the technique employed in this study.

The Johansen $(1991,1995)$ technique has become an essential tool in the estimation of models that involve time series data. This approach is preferred as it captures the underlying time series properties of the data and is a systems equation test that provides estimates of all cointegrating relationships that may exist within a vector of nonstationary variables or a mixture of stationary and nonstationary variables (Harris, 1995: 80). The Johansen technique has several advantages over other cointegration based techniques. The Johansen technique is preferred in this study as it allows for the estimation of a dynamic error correction specification, which provides estimates of both the short and the long run dynamics in the empirical model. A number of steps are required in estimating the Johansen technique and these include, to determine the stationarity of the variables in the empirical model, the next step is performing cointegration tests in order to identify any long run relationships between the variables, a short run vector error correction model is then estimated on condition of finding cointegration in the previous step and finally, residual diagnostics tests form the last step. Impulse response and variance decomposition is to be performed when the variables pass the necessary diagnostics tests.

\subsection{Testing for stationarity/unit root}

A series is referred to as (weakly or covariance) stationary if its mean and variance are constant over time and "the value of the covariance between the two time periods depends only on the distance or lag between the two time periods, not on the time at which the covariance is calculated" (Gujarati, 2003:797). A series that is not stationary is referred to as nonstationary. In addition, a series is said to be integrated and is denoted as I(d), where $d$ is the order of integration. The order of integration refers to the number of unit roots in the series, or the number of differencing operations it takes to make a variable stationary.

In the classical regression model, we deal with the relationship between stationary variables, but most of the economic indicators usually follow a nonstationary path. Variables that have a linear relationship (non-stationary) can lead to misleading results as they might show trends. Stationarity refers to testing and making sure that the series are integrated of the same order. Gujarati (2003: 806) shows that if the dependent variable is a function of a nonstationary process, the regression will produce spurious results (a nonsense regression). In other words, the dependent variable will follow the trend of its explanatory variables. In such a case, the results will be meaningless. In fact, it is likely that significant t-ratios and a high $\mathrm{R}^{2}$ will be obtained even though the trending variables are completely unrelated. Consequently, unit root or stationarity tests should be done on all the variables before proceeding with the tests for cointegration and estimation of parameters. There are a number of stationarity tests applied in econometric modelling, however this study adopts the Augmented Dickey Fuller (ADF) in its analysis.

\subsection{Augmented Dickey Fuller test}

The ADF test is a stricter version of the DF test. The ADF test estimates three models for each of the variable as shown below; 
The equation with no constant and no trend is represented by;

$\Delta \mathrm{y}_{\mathrm{t}}=\mathrm{y} \mathrm{y}_{\mathrm{t}-1} \sum_{i=2}^{p} \beta i \Delta \mathrm{y}_{\mathrm{t}-1+1}+\mu_{\mathrm{t}}$.

The equation with a constant and no trend is represented

$\Delta \mathrm{y}_{\mathrm{t}}=\mathrm{a}_{0}+\mathrm{y}_{\mathrm{t}-1}+\sum_{i=2}^{p} \beta i \Delta \mathrm{y}_{\mathrm{t}-1+1}+\mu_{\mathrm{t} .}$.

The equation with both a trend and a constant is given by;

$\Delta \mathrm{y}_{\mathrm{t}}=\mathrm{a}_{0}+\mathrm{y}_{\mathrm{t}-1} \mathrm{a}_{2} \sum_{i=2}^{p} \beta i \Delta \mathrm{y}_{\mathrm{t}-1+1}+\mu_{\mathrm{t}}$.

In these models;

$=\gamma-\left(1-\sum_{i=1}^{p} \alpha \mathrm{i}\right)$

And

$\beta=-\sum_{i=1}^{p}$ ai

The ADF test corrects for high-order serial correlation by adding a lagged differenced term on the right-hand side in the DF equations. The null $(\gamma=0)$ and alternative hypothesis for the ADF test is the same as the DF test. In both tests, if the calculated statistic is less (in absolute terms) than the MacKinnon $(1991,1996)$ values, which are used by the E-views 7 software, the null hypothesis is accepted and will therefore mean that there is a unit root in the series. In other words, it means the time series is not stationary. The opposite is true when the calculated statistic is greater than the MacKinnon critical values. However, in this ADF equation the coefficient of interest is $\gamma$, if $\gamma=0$, the equation is entirely in first difference form and so has no unit root. If the coefficients of a difference equation sum up to 1 , at least one characteristic root has unity. On the equations, if $\sum a i=1, y=0$ and the system has a unit root.

\subsection{Diagnostics Check}

Any econometric estimation technique whether OLS or VAR is not considered robust and valid unless diagnostics tests are done. Diagnostics checks test the validity and usefulness of the estimated model. Diagnostic checks test the stochastic properties of the model, such as residual autocorrelation, heteroskedasticity and normality, among others.

\subsubsection{Autocorrelation LM Test}

The Lagrange Multiplier (LM) test used in this study is a multivariate test statistic for residual serial correlation up to the specified lag order. Harris (1995: 82) argues that the lag order for this test should be the same as that of the corresponding VAR. The test statistic for the chosen lag order $(\mathrm{m})$ is computed by running an auxiliary regression of the residuals (t $\mu$ ) on the original right-hand explanatory variables and the lagged residuals ( $\mathrm{m} \mathrm{t}-\mu$ ). Johansen (1995: 22) presents the formula of the LM statistic and provides detail on this test. The LM statistic tests the null hypothesis of no serial correlation against an alternative of autocorrelated residuals (Takaendesa, 2006).

\subsubsection{White heteroscedasticity test}

This test is an extension of White's (1980) test to systems of equations, it tests the null hypothesis that the errors are both homoskedastic (no heteroskedacity problem) and independent of the regressors and that there is no problem of misspecification. The test regression is run by regressing each cross product of the residuals on the cross products of the regressors and testing the joint significance of the regression. The failure of any one or more of the conditions just mentioned above could lead to a significant test statistic. Thus, under the null of no heteroskedacity and no misspecification, the test statistic should not be significant (Takaendesa, 2006).

\subsubsection{Residual normality test}

One of the most commonly applied tests for normality is the Jarque-Bera (JB) test. The residual normality test used in this study is the multivariate extension of the Jarque-Bera test which compares the third and fourth moments of the residuals to those from the normal distribution. The joint test is based on the null hypothesis that residuals are normally distributed. A significant Jarque-Bera statistic, therefore, points to non-normality in the residuals. However, the absence of normality in the residuals may not render cointegration tests invalid (Takaendesa, 2006).

\section{Empirical Results}

This section presents the empirical results. 


\subsection{Test for stationarity}

This is the first step required by Johansen estimation technique. As stated earlier in this paper Augmented Dickey-Fuller tests are applied. The results of this test are presented in figure 4 below:

Figure 4: Non stationary variable at levels
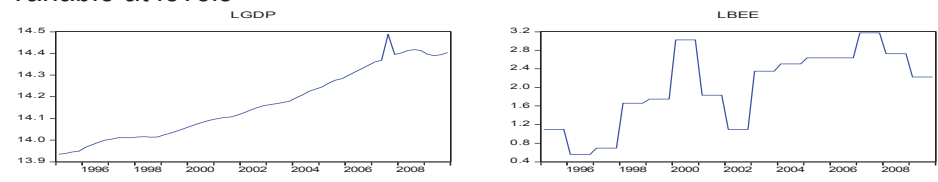

LGFCI
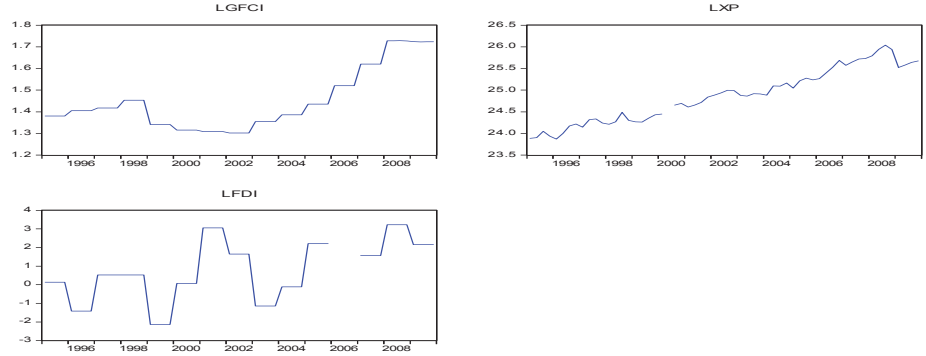

As it can be noted in figure 4 above, all variables have unit root in levels. The variables had to be differenced in order to become stationary. Augmented Dickey Fuller test results are shown in table 3 below:

Table 3: Stationarity test

\begin{tabular}{|c|c|c|c|c|}
\hline \multirow[t]{2}{*}{ Series } & \multirow[t]{2}{*}{ Model } & \multicolumn{3}{|c|}{$A D F$} \\
\hline & & Lags & $T_{T} T_{\mu} T$ & $\varphi_{3} \varphi_{1}$ \\
\hline \multirow{3}{*}{ Ingdp } & $T_{T}$ & 1 & -0.319980 & 5.0 \\
\hline & $T_{\mu}$ & 0 & -2.821164 & 3.98 \\
\hline & $T$ & 1 & $4.053167^{*}$ & \\
\hline \multirow{3}{*}{$\Delta$ lngdp } & $T_{T}$ & 0 & -11.30391 & $127.7^{*}$ \\
\hline & $T_{\mu}$ & 0 & -11.20244 & $62.7^{*}$ \\
\hline & $T$ & 0 & $-9.356730^{*}$ & \\
\hline \multirow{3}{*}{ Inbee } & $T_{T}$ & 0 & -1.837837 & 3.37 \\
\hline & $T_{\mu}$ & 0 & -2.330271 & 2.81 \\
\hline & $T$ & 0 & -0.294844 & \\
\hline \multirow{3}{*}{$\Delta$ Inbee } & $T_{T}$ & 0 & -7.506233 & $56.3^{*}$ \\
\hline & $T_{\mu}$ & 0 & -7.466671 & $27.8^{*}$ \\
\hline & $T$ & 0 & $-7.549834^{*}$ & \\
\hline \multirow{3}{*}{ Ingfci } & $T_{T}$ & 0 & 0.431593 & 0.18 \\
\hline & $T_{\mu}$ & 0 & -0.944034 & 1.90 \\
\hline & $T$ & 0 & 1.583662 & \\
\hline \multirow{3}{*}{$\Delta$ Ingfci } & $T_{T}$ & 3 & -2.178356 & 22.0 \\
\hline & $T_{\mu}$ & 0 & -8.164442 & $33.3^{*}$ \\
\hline & $T$ & 3 & $-2.048297^{* *}$ & \\
\hline \multirow{3}{*}{ Infdi } & $T_{T}$ & 8 & -0.884032 & 12.2 \\
\hline & $T_{\mu}$ & 8 & -1.650295 & 11.6 \\
\hline & $T$ & 8 & -0.629754 & \\
\hline \multirow{3}{*}{$\Delta$ lnfdi } & $T_{T}$ & 7 & -8.249531 & $33.6^{*}$ \\
\hline & $T_{\mu}$ & 7 & -8.101271 & $28.8^{*}$ \\
\hline & $T$ & 7 & $-8.409786^{*}$ & \\
\hline \multirow[t]{3}{*}{$\ln x p$} & $T_{T}$ & 0 & -0.854643 & 0.73 \\
\hline & $T_{\mu}$ & 0 & -3.078683 & 4.77 \\
\hline & $T$ & 0 & 1.934423 & \\
\hline \multirow[t]{3}{*}{$\Delta \ln x p$} & $T_{T}$ & 0 & -7.325987 & $53.7^{*}$ \\
\hline & $T_{\mu}$ & 0 & -7.267255 & $26.4^{*}$ \\
\hline & $T$ & 0 & -6.948724 & $42.9^{*}$ \\
\hline
\end{tabular}

$\left.{ }^{*}{ }^{* *}\right)\left[{ }^{* * *}\right]$ Statistically significant at a 1(5)[10]\% level 
Table 3 shows that all variables have unit root in levels but became stationary after first difference. GDP became stationary in all cases (constant and no trend, constant and trend, no constant and no trend) at $1 \%$ level of significance. BEE became stationary in all cases (constant and no trend, constant and trend, no constant and no trend) at $1 \%$ level of significance. GFCF became stationary after first difference (constant and trend at $1 \%$ level of significance and no constant and no trend at $5 \%$ level of significance). FDI became stationary in all cases (constant and no trend, constant and trend, no constant and no trend) at $1 \%$ level of significance. Xp became stationary in all cases (constant and no trend, constant and trend, no constant and no trend) at $1 \%$ level of significance. The null hypothesis of unit root is therefore rejected and the alternative of no unit root in the series is accepted. The unit root test using constant and no trend assumption shows the most robust results for all tests. The variables are integrated of the order I(1) as shown in figure 5 below:

Figure 5: Stationary variables after differencing
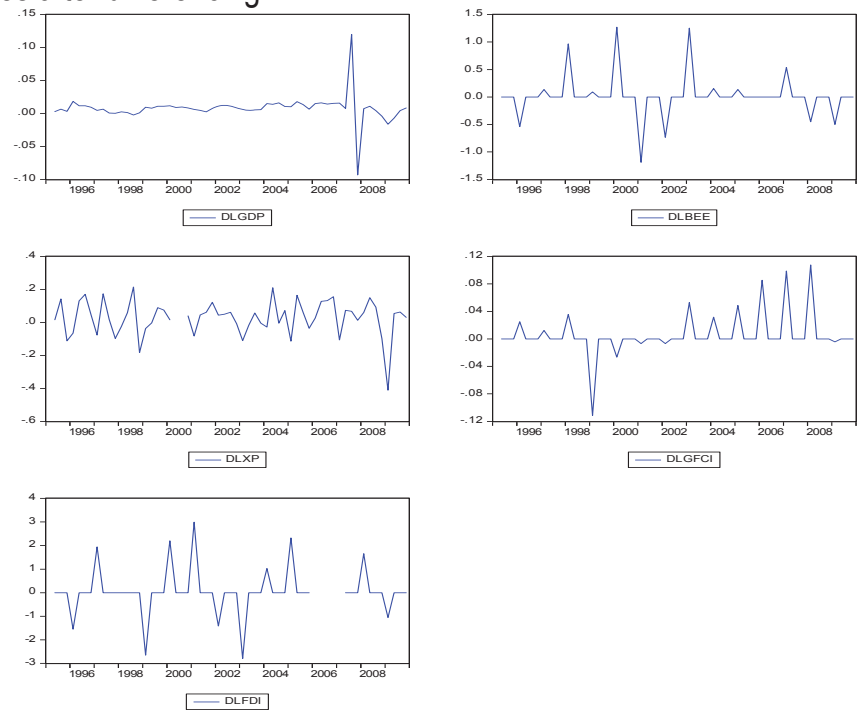

DLGFCI

The next step was to perform a vector autoregression on the above variables. Before we estimate equations, we had to decide on the maximum lag length $\mathrm{k}$ considering that too many lagged terms consume degrees of freedom, needless to mention the possibility of multicollinearity. Also including too few lags will lead to specification errors. One way of deciding this question was to use the Akaike or Schwarz criterion and choose a model that gives the lowest values of these criteria. Table 4 below shows the lag length criteria obtained from the unrestricted VAR. The information criterion approach produces results which indicate a choice of lag 1. An optimal lag length is required to produce uncorrelated and homoskedastic residuals.

Table 4: Lag Length Criteria

\begin{tabular}{|c|c|c|c|c|c|c|}
\hline Lag & LogL & LR & FPE & AIC & SC & HQ \\
\hline 0 & 3.567107 & NA & $7.36 \mathrm{e}-07$ & 0.066646 & 0.271437 & 0.142167 \\
\hline 1 & 244.6885 & 414.9532 & $3.20 \mathrm{e}-11$ & -9.985514 & $-8.756770^{*}$ & $-9.532391^{*}$ \\
\hline 2 & 271.6743 & $40.16486^{*}$ & $3.06 \mathrm{e}-11^{*}$ & $-10.07788^{*}$ & -7.825177 & -9.247150 \\
\hline 3 & 283.5491 & 14.91246 & $6.42 \mathrm{e}-11$ & -9.467398 & -6.190746 & -8.259070 \\
\hline 4 & 307.9199 & 24.93762 & $8.64 \mathrm{e}-11$ & -9.438135 & -5.137530 & -7.852205 \\
\hline 0 & 3.567107 & NA & $7.36 \mathrm{e}-07$ & 0.066646 & 0.271437 & 0.142167 \\
\hline
\end{tabular}

* indicates lag order selected by the criterion

LR: sequential modified LR test statistic (each test at $5 \%$ level)

FPE: Final prediction error

AIC: Akaike information criterion

SC: Schwarz information criterion

$\mathrm{HQ}$ : Hannan-Quinn information criterion

Based on the information given in table 4 above the maximum lag length chosen is $=2$ (using Akaike information criterion. Having chosen the maximum lag length the next step is to test for cointegration amongst variables. 


\subsection{Test for Cointegration}

Cointegration analysis was conducted using the Johansen procedure to determine whether there is a long run equilibrium relationship between poverty and its determinants. The procedure involved specifying the optimal leg length and choosing of the deterministic assumption that the Johansen test requires.

Table 5: Unrestricted Cointegration Rank Test (Trace)

\begin{tabular}{|c|c|c|c|c|}
\hline Hypothesized No. of CE(s) & Eigenvalue & Trace Statistic & 0.05 Critical Value Prob. $^{* *}$ \\
\hline None $^{*}$ & 0.543385 & 86.74911 & 69.81889 & 0.0013 \\
\hline At most 1 $^{*}$ & 0.337615 & 53.04079 & 47.85613 & 0.0151 \\
\hline At most 2 & 0.310691 & 35.32874 & 29.79707 & 0.0104 \\
\hline At most 3 & 0.256995 & 19.32989 & 15.49471 & 0.0125 \\
\hline At most 4 & 0.141424 & 6.556634 & 3.841466 & 0.0104 \\
\hline
\end{tabular}

Trace statistics indicate 5 cointegrating equations at $5 \%$ level.

*Denotes rejection of hypothesis at $5 \%$ level

${ }^{* *}$ MacKinnon-Haug-Mitchellis (1999) p-values

Table 6: Unrestricted Cointegration Rank Test (Maximum Eigenvalue)

\begin{tabular}{|c|c|c|c|c|}
\hline Hypothesized No. of CE(s) & Eigenvalue & Trace Statistic & 0.05 Critical Value & Prob. $^{* *}$ \\
\hline None & 0.543385 & 33.70832 & 33.87687 & 0.0524 \\
\hline At most 1 & 0.337615 & 17.71204 & 27.58434 & 0.5192 \\
\hline At most 2 & 0.310691 & 15.99885 & 21.13162 & 0.2249 \\
\hline At most 3 & 0.256995 & 12.77326 & 14.26460 & 0.0849 \\
\hline At most 4 & 0.141424 & 6.556634 & 3.841466 & 0.0104 \\
\hline None & 0.543385 & 33.70832 & 33.87687 & 0.0524 \\
\hline
\end{tabular}

Max_eigenvalue test indicates no cointegration at 0.05 level.

*denotes rejection of the hypothesis at the 0.05 level

**MacKinnon-Haug-Michelis (1999) p-values.

Table 5 above represents the Trace test whilst table 6 represents the Maximum Eigenvalue test. The Trace test indicates 5 cointegrating eqn(s) at the 0.05 level. Table 6 shows that there is no cointegrating relationship in the empirical model at the 0.05 level. Since Trace test gives evidence of cointegration, we run a vector error correction model. The next section of the paper provides restricted VAR results.

\subsection{Vector Error Correction Model (VECM)}

The VECM specify the short-run dynamics of each variable in the system, and in a framework that anchors the dynamics to long-run equilibrium relationships suggested by economic theory. Having established that the variables concerned are cointegrated, it is appropriate to estimate an ECM. In particular, in an ECM, the short-term dynamics of the variables in the system are influenced by the deviation from equilibrium.

$$
\mathrm{P}^{\Delta Y t}=\theta_{1} \Delta X t+\theta_{2}\left(Y_{t-1}-\gamma_{x t-1}\right)+\mu t \ldots
$$

The error correction term is given by $Y_{t-1}-\gamma_{x t-1}$. The implied coefficient of $X_{t-1}$ of one in this term suggests a proportional long run relationship between $Y$ and $X$. Error correction models are interpreted as: $Y$ is purported to change between $t-1$ and $t$ as a result of changes in the values of the explanatory variables $X$ between $t-1$ and $t$, and also in part to correct for any disequilibrium that existed during the previous period. The error correction term would appear without any lag for this would imply that y changes between $t-1$ and $t$ in response to a disequilibrium at time $t . \gamma_{\text {defines the long run }}$ relationship between $X$ and $Y$ while $\beta_{1}$ describes the short run relationship between changes in $x$ and changes in $y$. $\beta_{2}$ describes the speed of adjustment back to equilibrium, and by definition it measures the proportion of last period's equilibrium error that is corrected for.

According to Asteriou and Hall (2007:310-311) the ECM is important and popular for many reasons such as that it is a convenient model measuring the correction from disequilibrium of the previous period which has a very good economic implication. In addition, since ECMs are formulated in terms of the first differences, this typically eliminates trends from the variables involved and therefore they resolve the problem of spurious regressions. The other advantage of ECMs is the ease with which they can fit into the general-to-specific approach to econometric modelling, which is in 
fact a search for the most parsimonious ECM model that best fits given data sets. Lastly, the fact that the disequilibrium error term is stationary (by definition of cointegration) the ECM has important implications such as: the fact that the two variables are cointegrated implies that there is some adjustment process which prevents the errors in the long run relationship become larger and larger.

Vector error correction estimates are portrayed in tables 7 below:

Table 7: VECM results (Dependent variable DLGDP)

\begin{tabular}{|c|c|c|c|c|c|}
\hline Variable & Coefficient & Standard Error & t-stat & & \\
\hline DLBEE(-1) & -0.019636 & 0.01127 & -1.74163 & & \\
\hline DLXP(-1) & -0.259062 & 0.03795 & -6.82638 & & \\
\hline DLGFCI(-1) & 0.096620 & 0.15482 & 0.62406 & & \\
\hline DLFDI & 0.009160 & 0.00448 & 2.04626 & & \\
\hline $\mathrm{C}$ & 0.001696 & & & & \\
\hline Error Correction: & $\overline{D(D L G D P)}$ & $\mathrm{D}$ (DLBEE) & $\mathrm{D}(\mathrm{DLXP})$ & $\mathrm{D}$ (DLGFCl) & D(DLFDI) \\
\hline \multirow[t]{3}{*}{ CointEq1 } & 0.075596 & 4.516594 & 6.857639 & -0.043498 & -15.75383 \\
\hline & $(0.09400)$ & $(5.87677)$ & $(1.37671)$ & $(0.37599)$ & (14.7285) \\
\hline & {$[0.80420]$} & [0.76855] & [4.98118] & {$[-0.11569]$} & {$[-1.06962]$} \\
\hline
\end{tabular}

The results portrayed in table 7 above indicates that black economic empowerment transactions (DLBEE) have a negative relationship with GDP in the long but a positive relationship in the short run. However the relationship between GDP and BEE is statistically insignificant both in the long run and short run. Exports (DLXP) are positively related to GDP in the short run but have a negative relationship in the long run. The relationship between exports and GDP is statistically significant both in the short run and in the long run. DLGFCl (gross fixed capital investment) has a positive relationship with GDP in a long run but a negative one in the short run. The relationship both in the long run and the short run is statistically insignificant. DLFDI (foreign direct investment) has a statistically significant positive relationship with GDP in the long run but a negative and statistically insignificant relationship with GDP in the short run.

\subsection{Impulse response analysis}

Impulse response analysis traces out the responsiveness of the dependent variable in the VAR to shocks to each of the other variables. It shows the sign, magnitude and persistence of shocks in any of the explanatory variables. A shock to a variable in a VAR not only directly affects that variable, but is also transmitted to all other endogenous variables in the system through the dynamic structure of the VAR. For each variable from the equations, separately, a unit or one-time shock is applied to the forecast error and the effects upon the VAR system over time are observed. The impulse response analysis is applied on the VECM and, provided that the system is stable, the shock should gradually die away (Brooks, 2002: 341). There are several ways of performing impulse response analysis, but the Cholesky orthogonalisation approach to impulse response analysis, which is a multivariate model extension of the Cholesky factorization technique, is preferred in this paper. This approach is preferred because, unlike other approaches, it incorporates a small sample degrees of freedom adjustment when estimating the residual covariance matrix used to derive the Cholesky factor (Lütkepohl, 1991: 155-158).

Figure 6: Impulse response

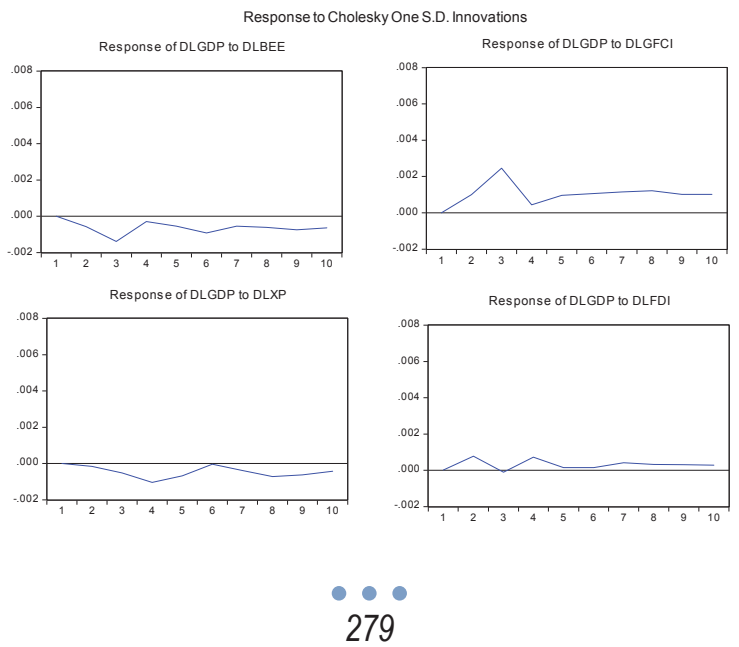


These impulse response functions show the dynamic response of GDP to a one-period standard deviation shock to the innovations in the system and also indicate the directions and persistence of the response to each of the shocks over a 10 quarter (2.5years) period. For most part, the impulse response functions confirm the results from the long run relationship analysis. In figure 6 above, a shock in BEE is not significantly different from zero and has a marginal negative impact on GDP over a period of 2.5 years. Likewise a one period standard deviation shock to exports marginally depresses growth and is transitory. A shock to FDI results in positive impact on economic growth and remains positive for a period of 2.5 years. A shock to $\mathrm{GFCl}$ results in a positive impact on the economy and remains positive over a period of 2.5 years.

\subsection{Variance decomposition analysis}

Variance decompositions analysis measures the proportion of forecast error variance in a variable that is explained by innovations in itself and the other variables. Variance decompositions performed on the VECM give the proportion of the movements in the dependent variables that are due to their 'own' shocks versus shocks to the other variables (Brooks, 2002: 342). Brooks also observed that own series shocks explain most of the forecast error variance of the series in a VAR. The same factorization technique and information used in estimating impulse responses is applied in the variance decompositions.

Table 8: Variance decomposition

\begin{tabular}{|c|c|c|c|c|c|c|}
\hline Period & S.E. & DLGDP & DLBEE & DLXP & DLGFCl & DLFDI \\
\hline 1 & 0.007326 & 100.0000 & 0.000000 & 0.000000 & 0.000000 & 0.000000 \\
\hline 2 & 0.008217 & 97.06875 & 0.499969 & 0.036919 & 1.498671 & 0.895693 \\
\hline 3 & 0.009630 & 88.92183 & 2.463343 & 0.316359 & 7.633748 & 0.664723 \\
\hline 4 & 0.010485 & 88.92894 & 2.156104 & 1.259084 & 6.618756 & 1.037118 \\
\hline 5 & 0.011322 & 89.17130 & 2.081576 & 1.433441 & 6.408323 & 0.905357 \\
\hline 6 & 0.012159 & 89.27241 & 2.375866 & 1.243892 & 6.308664 & 0.799166 \\
\hline 7 & 0.012920 & 89.34359 & 2.280484 & 1.189196 & 6.377084 & 0.809647 \\
\hline 8 & 0.013637 & 89.09329 & 2.253228 & 1.350481 & 6.523005 & 0.779996 \\
\hline 9 & 0.014292 & 89.05230 & 2.328514 & 1.416025 & 6.449979 & 0.753186 \\
\hline 10 & 0.014928 & 89.20411 & 2.320409 & 1.377018 & 6.372820 & 0.725643 \\
\hline \multicolumn{7}{|l|}{ Cholesky Ordering: DLGDP DLBEE DLXP DLGFCI DLFDI } \\
\hline
\end{tabular}

Throughout the period of 2.5 years, a large proportion of variations in GDP are due to itself. However, looking at the contributions of the other explanatory variables towards variation in GDP from the third period onwards; gross fixed capital investment contributes $7.6 \%$ towards a variation in GDP whilst BEE contributes only $2.4 \%$. Throughout the 10 periods, gross fixed capital investment maintains a greater proportion towards GDP variation compared to other explanatory variables. Black economic empowerment accounts only for $2.2 \%$ to $2.3 \%$ contribution towards GDP variation over the ten periods.

\subsection{Diagnostic tests}

Diagnostic checks are crucial in this analysis because if there is a problem in the residuals from the estimation of the model, it is an indication that the model is not efficient, such that parameter estimates from such a model may be biased. Results for the diagnostic tests are presented in the following section.

Serial Correlation LM Tests

Table 9: Serial Correlation tests

\begin{tabular}{|c|c|c|}
\hline Lags & LM-Stat & Prob \\
\hline 1 & 28.42956 & 0.2885 \\
\hline 2 & 29.38154 & 0.2483 \\
\hline
\end{tabular}

The results in table 9 above suggest that the null hypothesis of no serial correlation cannot be rejected, thus concluding that the residuals are not serially correlated. 


\subsubsection{Heteroscedasticity}

Table 10: VEC Residual Heteroskedasticity Tests

\begin{tabular}{|c|c|c|}
\hline Chi-sq & df & Prob. \\
\hline 291.5527 & 330 & 0.9373 \\
\hline
\end{tabular}

The results in table 10 above suggest that a null hypothesis of no heteroscedasticity cannot be rejected thus concluding that the residuals are homoscedastic.

\subsubsection{Normality test}

Table 11: Normaliy test

\begin{tabular}{|c|c|c|c|}
\hline Component & Chi-Sq & Df & Prob \\
\hline Joint & 43.49273 & 5 & 0.0000 \\
\hline
\end{tabular}

The results in table 11 above indicate a significant $p$ - value $(0.0000)$ meaning that the null hypothesis of no normality can be rejected. We therefore conclude that the data is normally distributed.

All the diagnostic tests carried out on the data reveal that the model is reasonably well specified. All of the diagnostic tests support the statistical appropriateness of the equation.

\subsubsection{AR Roots test}

The AR Roots Graph reports the inverse roots of the characteristic AR polynomial. The estimated VAR is stable (stationary) if all roots have modulus less than one and lie inside the unit circle. If the VAR is not stable, certain results such as impulse response standard errors are not valid. Figure 7 shows that all roots lie inside the unit circle which is an indication that our VAR is stable.

Figure 7: Inverse Roots of AR Characteristic Polynomial

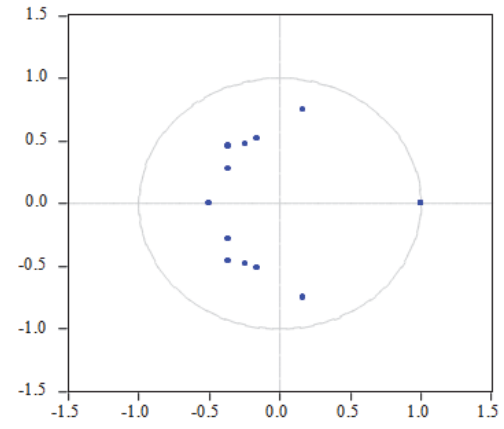

\subsubsection{Granger Causality}

Granger causality is a circumstance in which one time series variable consistently and predictably changes before anther variable does (Granger,1969). If one variable precedes (granger causes) another, we still cant be sure that the first variable 'causes' the other to change, but we can be fairly sure that the opposite is not the case.

Table 12 below presents the results of granger causality between GDP and BEE in South Africa.

Table 12: Granger Causality test

\begin{tabular}{|c|c|c|c|}
\hline Null Hypothesis & Obs & F-Statistic & Prob \\
\hline DLBEE does not Granger Cause DLGDP & \multirow{2}{*}{57} & 0.57406 & 0.5668 \\
\cline { 4 - 4 } & & 0.51368 & 0.6013 \\
\hline
\end{tabular}

The results in table 12 above indicate that the null hypothesis that Black Economic Empowerment (DLBEE) does not Granger Cause economic growth (DLGDP) cannot be rejected ( $p$-value $>5 \%$ ) and vice versa. 


\section{Implications of the Findings}

The main objective of this paper was to assess the impact of Black Economic Empowerment on economic growth in South Africa. The thrust of the argument is whether or not Black Economic Empowerment is a catalyst to growth in the South African economy. Our argument is based on the fact that Black Economic Empowerment is implemented against a backdrop of historical repressive policies against black businesses in South Africa during the apartheid era. These repressive policies were geared at ensuring that no successful black businesses should emerge in South Africa (Tager, 1988). Accordingly the failure of a number of BEE deals can be attributed to the state of unreadiness by black people to engage in successful entrepreneurial ventures. The continuous "xenophobic" attacks on successful foreign owned informal businesses in the South African townships attest to this lack of business skills amongst a number of black businesses in South Africa. The legacy and the scars of apartheid run deeper than just a political front but also impinge on the economic struggles of the peoples of South Africa.

Black Economic Empowerment policy came into view as a potential mechanism for dealing with structural issues affecting economic growth and racial access. However the results of this study show that Black Economic Empowerment has failed to translate into a sustainable economic growth in South Africa. This paper gave evidence to the fact that BEE does not granger cause economic growth and neither does economic growth granger cause BEE. This research further proves that a shock in BEE results in a negative impact on economic growth which lasts almost 2.5 years. It is on the basis of these findings that the null hypothesis in this study cannot be rejected.

The results of this study are in line with other scholars. For example, Sanchez (2011) points out that the BEE strategy faces several challenges which can be broadly classified as implementation, structural and attitudinal challenges. According to Roberts (2009) a major implementation obstacle has been the lack of financial resources both amongst black individuals and communities and in public sources to fund BEE deals. The second obstruction identified by Roberts (2009) is; given the apartheid history of low quality education for the black majority, finding qualified employees, particularly managers is problematic. This is further aggravated by a fierce competition between companies to attract qualified black individuals which results in low retention rates. Similarly the lack of business experience amongst most black South Africans makes finding equity partners with business skills difficult. Third, in terms of procurement, given the lack of entrepreneurial experience and tradition amongst black businesses, big companies struggle to find reliable and suitable suppliers with good BEE credentials. Roberts (2009) points out the issue of skills transfer, a key element for sustainable empowerment, which has also been identified by some companies as a major challenge as they battle to set aside time and resources to comply with this task. Consequently, many companies have decided to pay non-compliance fees instead of investing time and money in getting their skills programmes right.

Structural challenges on the other side involve the structure of the state and the South African economy has in general hindered the transfer of one of the key priorities, ownership. Sanchez (2011) points out that as the economy is greatly dominated by large corporates, change of ownership requires massive amounts of capital, which, given the history of economic discrimination, are not available for the great majority of the black population.

BEE strategy has according to Sanchez (2011) encountered attitudinal challenges which refer mainly to a lack of understanding on the importance of the BEE strategy. This lack of understanding is reflected in resistance to transformation and lack of buy-in into the strategy which naturally affects implementation. While the public discourse is largely supportive of transformation, many large companies have also publicly raised their concerns and uncertainty.

Thus, whereas partaking in existing economic corporation is important, the creation of new black-owned and black controlled enterprises is fundamental. Consequently, entrepreneurship and radically improving education and skills amongst the country's youth need to be particularly prioritised and promoted. Socio-economic empowerment is more likely to be achieved and sustained if it creates a large pool of educated youngsters who will either access the labour market or create small businesses to absorb those affected by the current high unemployment rate.

\section{Recommendations}

More investment in black-owned and black-empowered companies is a crucial step in the provision of financial and intellectual capital. The key focus must be to ensure that there is a real economic benefit flowing to the recipient enterprise to empower it to be set up and run on a sustainable basis; effectively there must be resultant operational capacity from the investment into the enterprise; and, there must be active participation by black people in the recipient enterprise.

Joint ventures with black enterprises must include processes such as outsourcing parts of the established company's projects or jointly contracting for certain projects that will ultimately lead to a transfer of skills to the black 
company. Thus, the next step then should be to measure the effectiveness of joint ventures on whether or not the black company is able to perform the core elements of the joint projects on a stand-alone basis without compromising the competitive advantage contributed by either company.

Further, black owned enterprises should form coalitions with other black owned enterprises. This coalition will go a long way in benefiting the economy at large on BEE deals since there will be shared experiences as well as skills transfer. There are a number of black entrepreneurs that already possess the necessary skills and knowledge to become successful in businesses. However, they do not have the requisite startup or other forms of support and training or even literacy to establish or manage businesses. These are the individuals that the broad-based black economic empowerment policy should prioritise for positive action and support in order to impact economic growth positively.

Such changes in the approach for broad-based black economic empowerment will have the effect of benefitting the entire country. The Gross Domestic Product will obviously improve and more wealth will be equitably distributed. There will be less dependency upon external financial resources to meet the needs of the country. Wealth generated internally, will obviously contribute to the generation of taxes that will be available to the government. In turn, individuals will be less dependent upon the government for social grants. People will be self-reliant, produce sustainable products and need a space to grow and export products. Broad-based black economic empowerment policy should also extend to youth economic empowerment such that the young generation is taken on board towards entrepreneurship ventures.

\section{References}

Andrews, M. (2008). Is Black Economic Empowerment a South African Growth Catalyst? John F. Kennedy School of Government Harvard University, RWP08-033

Banda, L., Herzenberg, C., \& Paremoer, L. (2003). Black Economic Empowerment: Addressing Socio Economic Inequality in South Africa. Idasa Political Information and Monitoring Services

Barker, F. (2005). South African Labour Market. Pretoria:Van Schaick.

Berry, A., Von Blottnitz, M., Cassim, C., Kesper, A., Rajaratnam, B., and Van Seventer, D.E. (2002). The Economics of SMMEs in SA. Pretoria: TIPS Report.

Brooks,C. (2008). Econometrics for Finance.United Kingdom: Cambridge University Press.

Cawker, G. \& Whiteford, A. (1993). Confronting Unemployment In South Africa. Pretoria: HSRC.

Development indicators. (2010). National Planning Commission.Pretoria: Government Printers.

Donaldson, R. \& van der Merwe, I. (1999). Deracialisation Of Urban Business Space: Street Traders In Pietersburg. Acta Academica $31(1): 140-166$.

DTI (Department of trade and Industry). (2003). South Africa's Economic Transformation: A strategy for Broad- Based Black Economic Empowerment. Retrieved January, 2007, from http://www.thedti.gov.za/bee

Dunnigan, R, Fazaeli, K and Spies, J. (2009). Black Economic Empowerment - difficulties and opportunities in making right the wrongs of the past

Engdahl, E.O. (2002). Rethinking Black Economic Empowerment in the Post-Apartheid South Africa. Graduate School of Public and Development Management: University of Witwatersrand.

Gqubule, T. (2006). New wave is short on impact. Financial Mail Top Economic Empowerment Companies, 90-93.

Granger, C. W. J. (1987). Long-run Economic Relationships. Oxford University Press: Oxford.

Gujarati, D. N. (2003). "Basic Econometrics".(4th edition). McGraw-Hill Inc: New York

Harris, R.(1995). "Using Cointegration Analysis in Econometric Modelling". Prentice Hall: London.

Hikam, A. (2011). An exploratory study on the Somali immigrants' involvement in the informal economy of Nelson Mandela Bay. Unpublished Masters Dissertation. Port Elizabeth: Nelson Mandela Metropolitan University.

IDASA. (2003). Poverty alleviation: Beyond the National Small Business Strategy. Occasional Paper: Institute for Democracy in Africa.

ILO (1999). The ILO's response to the financial crisis in East and South-East Asia. The Social Impact of the Asian Financial Crisis: An ILO Governing Body Symposium, GB.274/4/4, 274th Session, Geneva, March 1999.

Jack, V. (2007). Unpacking the different waves of Black Economic Empowerment. In Mangcu, X., G. Marcus, K. Shubane and A. Hadland (eds). Visions of Black Empowerment. Johannesburg: Jacana Press, 105-117.

Johansen, S. (1991). "Estimation and Hypothesis Testing of Cointegration Vectors in Gaussian Vector Autoregressive Models". Econometrica, 59:1551-1580.

Johansen, S. (1995). "Likelihood-Based Inference in Cointegrated Vector Autoregressive Models". Oxford University Press: Oxford.

Khumalo, G. \& Shane, S. (1995). The Post-Election Government's Small Business Support Policy. Policy Review Series. Johannesburg: Centre for Policy Studies.

KPMG. (2011). A Time for Transformational Leadership. 2011 BEE Survey

Mackinnon, J. G. (1991). "Critical Values for Cointegration Tests. In: Engle, R. F. and

Mackinnon, J. G.(1996). "Numerical Distribution Functions for Unit Root and Cointegration Tests". Journal of Applied Econometrics, 11: 601-618.

Macozoma, S. (2007). Black Economic Empowerment: De-racialising the economy. In Mangcu, X.G. Marcus, K. Shubane and A. 
Hadland (eds). Vision of Black Empowerment. Johannesburg: Jacana Press, 177-179

Manning, C. (1996). Market access for small and medium-sized 'producers in South Africa: the case of the furniture industry. Unpublished Ph.D. dissertation, University of Sussex, Brighton.

Mbeki, M.(2007). Concepts of transformation and the social structure of South Africa. In Mangcu, X., G. Marcus, K. Shubane and A. Hadland (eds). Visions of Black Empowerment. Johannesburg: Jacana Press, 216-226.

Meintjies, F. (2004). Black Economic Empowerment: Elite Enrichment or Real Transformation? Isandla Development Communique, No. 9 and 10

Mohr, P. Fourie, L. and Associates. (2008). Economics for South African students, $4^{\text {th }}$ ed. Van Schaik: Pretoria.

Mosdell, T. (1991). Power Patronage And Control: Ambiguities In The Deregulation Of Street Trading In Pietermaritzburg. In South Africa's informal economy: Contemporary South African debates. Cape Town: Oxford University Press.

Mosdell, T. (1994). Public Policy And The Informal Sector In South Africa: The Politics Of Street-Trading In Pietermaritzburg As An Illustrative Case. Unpublished Masters dissertation, University of Natal, Pietermaritzburg.

Ndu, C. (1997). Promoting Entrepreneurship In South Africa, With Particular Emphasis On Women Entrepreneurs Through Financing, Training And Cultural Empowerment. Southern African Entrepreneurship and Small Business Association, Potchefstroom University for Christian Higher Education.

Nzimande, B. (2007). The ethos of Black Economic Empowerment. In Mangcu, X., G. Marcus, K. Shubane and A. Hadland (eds). Visions of Black Empowerment. Johannesburg: Jacana Press, 180-187.

Phinda, M.M. (1997). Black economic empowerment in the new South Africa: The rights and the wrongs. Knowledge Resources.

Pressly, Donwald. (2007). BEE needs teeth if it is going to bite, state warned. Business Report, Thursday, August 62007 , Page 1.

Republic of South Africa. (1995). National strategy for the development and promotion of small business in South Africa. White Paper of the DTI. Cape Town

Roberts, B. (2009). 'Talking in class: Subjective indentification in South Africa' HSRC Review, Vol 7 No

Rogerson, C.M. \& Preston-Whyte, E. (1991). South Africa's Informal Economy: Past, Present And Future. Discussion Paper, University of the Witwatersrand.

Rogerson, C.M. (1997). SMMEs and Poverty in South Africa. Input Report for the National Project on Poverty and Inequality, May.

Rogerson, C.M. (1996). Rethinking The Informal Economy Of South Africa. Development Paper No. 84,.Development Bank of Southern Africa.

Sadler, E.(2001). "A profile and the work environment of black chartered accountants in South Africa." Meditari Accountancy Reseacrh, Vol. 10, 159-185.

Sanchez, D. (2011). The Economic Empowerment of African Descendents; lessons from South Africa's Black Economic Empowerment Strategy. HSRC, South Africa

Sims, C. A. (1980). Macroeconomics and Reality, Econometrica 48, 1- 48

Southall, R.(2005). "Black Empowerment and Corporate Capital" In State of the Nation $2004-2005$. www.ukzn.ac.za/ccs/files/Black\%20Empowerment\%20and\%20SA\%20Corporates.pdf

Strydom, PDF. 2006. Black Economic Empowerment in South Africa. Available: http://www.sabusinesshub.com/ section/content.php?Sectionld=23\&Subsectionld=12\&Contentld=1381

Tager, L. (1988). Deregulation In The South African Context: The Dismantling Of Socio-Economic Apartheid. Law Review Project. Johannesburg: University of the Witwatersrand.

Todaro, M.P. and Smith, S.C. (2010). Economic Development. England: Pearson Education Limited.

Van der Berg S. Burger R. Burger R. Louw M. and Yu D. (2005). Trends in poverty and inequality since the political transition. University of Stellenbosch. Stellenbosch Economic Working Papers: 01/05.

Van der Berg, S. and Louw, M. (2004). Changing Patterns of South African Income Distribution and Poverty, South African Journal of Economics, 72(3):546-572.

Van Eeden,S., Viviers,S., and Venter,D.(2003). A comparative study of selected problems encountered by small businesses in the Nelson Mandela, Cape Town and Egoli metropoles. Management Dynamics Volume 12 (3): 13 -23.

Van Scheers, L. (2010). Retail black economic empowerment compliant companies: cultural renewal in South Africa. Problems and Perspectives in Management, Volume 8, Issue 1, 2010

Ward, M and Muller, C.(2010). The long-term share price reaction to Black Economic Empowerment announcements on the JSE. Investment Analysts Journal, No. 712010.

White, H. (1980). "A Heteroskedasticity-Consistent Covariance Matrix and A Direct Test for Heteroskedasticity". Econometrica, 48: 817838. 